\title{
Conservative treatment of penile carcinoma - a retrospective study of 10 years
}

\author{
Tratamento conservador do carcinoma do pênis - \\ estudo retrospectivo de 10 anos
}

Neide Pereira ${ }^{1}$

Ricardo Vieira ${ }^{2}$

\author{
Ana Rita Cabral ${ }^{1}$ \\ Américo Figueiredo ${ }^{3}$
}

\begin{abstract}
Conservative treatment of penile squamous cell carcinoma has been advocated as a method of choice for tumours at early stages. Thirty patients with a mean age of 63.2 years were treated with CO2 laser ablation, radical local excision with preputial flap, direct closure or healing by secondary intention, circumcision alone or associated with CO2 laser and topical imiquimod. Sixteen patients had local recurrence. Partial penectomy was necessary in 3 patients. Conservative treatments of penile squamous cell carcinoma in early stages $(\leq \mathrm{T} 1 \mathrm{a})$ do not seem to compromise the survival rate, so it may be advisable for this subset of patients.
\end{abstract}

Keywords: Amputation; Laser therapy; Penile neoplasms

Resumo: O tratamento conservador do carcinoma espinocelular do pênis tem sido o método de escolha para tumores em estádios iniciais. Trinta doentes com idade média de 63,2 anos, foram tratados com: ablação com laser CO2, excisão radical seguida de retalho prepucial, encerramento direto ou cicatrização por segunda intenção, circuncisão isolada ou associada a laser CO2 e imiquimod. Dezasseis doentes apresentaram recidiva local. No seguimento, houve necessidade de penectomia parcial em 3 doentes. O tratamento conservador do carcinoma espinocelular do pênis em estádio $\leq$ T1a não parece comprometer a taxa de sobrevida, pelo que pode ser recomendável neste subgrupo de doentes.

Palavras-chave: Amputação; Neoplasias penianas; Terapia a laser

Penile squamous cell carcinoma (SCC) is an uncommon malignancy in developed countries with 0.1-0.7 cases per 100.000 habitants. ${ }^{1}$ Many epidemiologic studies have suggested several risk factors for the development of penile carcinoma including phimosis, chronic inflammatory conditions such as balanoposthitis and lichen sclerosus et atrophicus, previous phototherapy, sexual history, history of condylomata, smoking and uncircumcised men. ${ }^{2}$

Conventional treatment for penile carcinoma consists of partial or total amputation with a tumourfree margin of $2 \mathrm{~cm}^{3}$
Due to psychological and sexual consequences of penectomy, conservative surgical strategies have been developed. According to the latest European Association of Urology (EAU) Penile Cancer Guidelines, conservative treatment of penile SCC has been advocated as a method of choice for tumours at early stages (Tis, Ta and T1a). ${ }^{4}$ These organ-sparing treatment modalities include local excision, circumcision, Mohs micrographic surgery, glans resurfacing, laser ablation, photodynamic therapy, topical therapy with 5-fluorouracil, imiquimod 5\% cream, cryotherapy or radiotherapy. ${ }^{5}$

\footnotetext{
Received on 06.07.2012.

Approved by the Advisory Board and accepted for publication on 27.08.2012.

* Work carried out at the Dermatology and Venereology Service - Hospitals of the University of Coimbra (Universidade de Coimbra EPE, Service of Dermatology) - Coimbra - Portugal.

Conflict of interest: None

Financial Support: None

MD - Medical Intern in Dermatology and Venereology - Hospitals of the University of Coimbra (Universidade de Coimbra EPE, Service of Dermatology) Coimbra - Portugal.

MD - Specialist in Dermatology and Venereology - Hospitals of the University of Coimbra (Universidade de Coimbra EPE, Service of Dermatology) - Coimbra - Portugal.

Professor, PhD - Director of the Dermatology and Venereology Service - Hospitals of the University of Coimbra (Universidade de Coimbra EPE, Service of Dermatology) - Coimbra - Portugal. 
The aim of our study is to evaluate the efficacy of conservative treatment modalities in controlling loco-regional and systemic disease, in a retrospective study carried out in a 10-year period (2001-2010).

The authors conducted a retrospective study of 30 patients with penile SCC in stages TisN0M0, TaN0M0 and T1aN0M0, treated at the Department of Dermatology of the Coimbra University Hospital Dermatologic Surgery Unit, between 2001 and 2010.

Demographic data, risk factors, histological type, tumour location, treatment modalities, recurrence rates (local, regional and distant) and conversion into mutilating treatment during follow-up were evaluated.

Thirty patients with early-stage penile carcinoma were diagnosed and treated over a 10-year period at our department. The mean age was $63.2 \pm 15.6$ years-old, ranging from 31 to 87 years-old. In our series, some degree of phimosis was present in 4 patients $(13.3 \%), 5$ patients $(16.7 \%)$ had balanitis xerotica obliterans and $3(10 \%)$ had human papilloma virus infection.

The most common site was the glans $(77 \%$ of cases), either alone or in combination with other anatomical sites.
The histological diagnosis was erythroplasia of Queyrat in 13 cases, followed by Bowen's disease and verrucous SCC in 6 patients each, and invasive SCC in stage T1a in 5 patients. Summarizing, there were 19 $(63.3 \%)$ tumours staged as Tis, $6(20 \%)$ staged as Ta and $5(16.7 \%)$ staged as T1a. At diagnosis, no lymph node (N0) and distant metastasis (M0) were detected.

Carbon dioxide $\left(\mathrm{CO}_{2}\right)$ laser ablation was performed in 12 patients (40\%), radical excision followed by reconstruction with preputial flap in $6(20 \%)$, direct closure in $3(10 \%)$, healing by secondary intention in 1 $(3.3 \%)$, circumcision alone in $4(13.3 \%)$ or associated with $\mathrm{CO}_{2}$ laser in $3(10 \%)$ and imiquimod $5 \%$ cream in $1(3.3 \%)$ (Figures 1 and 2 ).

In a mean period of $42 \pm 32$ months (range: 3116 months), $53.3 \%(\mathrm{n}=16)$ of the patients had local recurrence. Five $(16.7 \%)$ patients had one recurrence, four $(13.3 \%)$ had two recurrences and seven $(23 \%)$ had three recurrences. The recurrence rates for Tis, Ta and T1a tumours were respectively $57.9 \%$ (11 out of 19 ), $66.7 \%$ ( 4 out of 6 ) and 20\% (1 out of 5 ). The mean relapse-free time was 15 months. Most of the 34 recurrences $(91.2 \%)$ were successfully treated with organsparing salvage therapy. Partial penectomy was necessary in 3 patients (10\%).

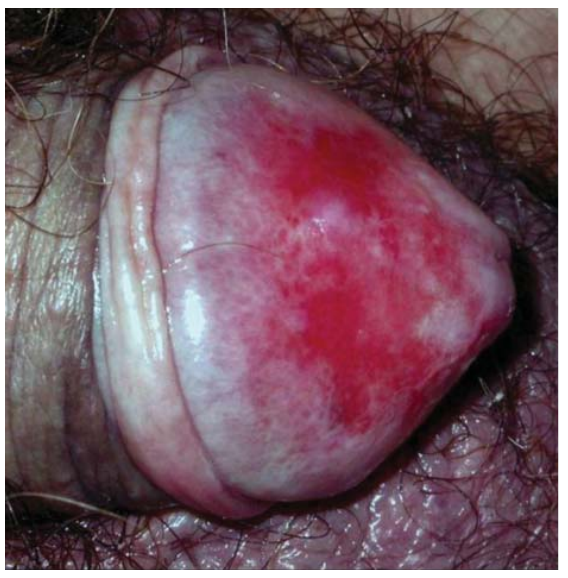

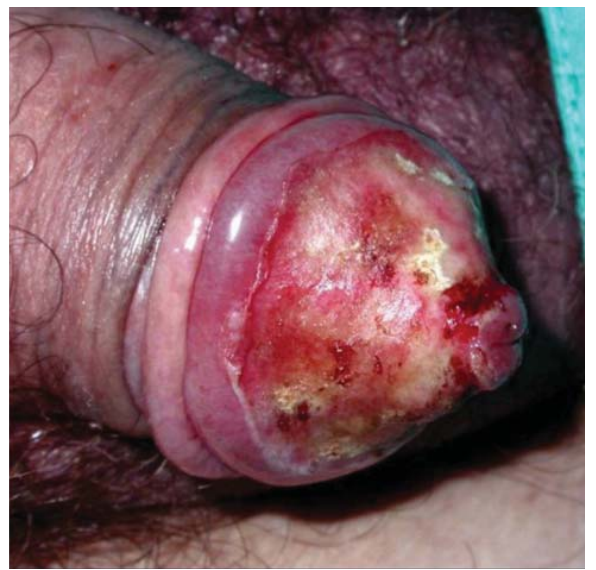

FIGURE 1: CO2 laser ablation
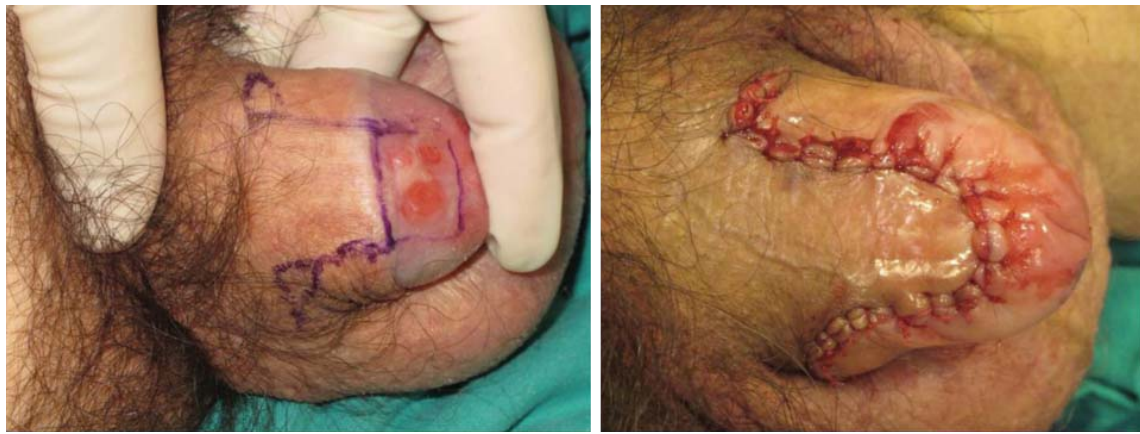

FIGURE 2: Radical excision followed by reconstruction with preputial flap 
There were no lymph nodes and visceral metastases during the follow-up and survival rate was $100 \%$.

The mean age of patients in our series is similar to other series reported in Europe. ${ }^{1}$ The relatively high frequencies of balanitis xerotica, phimosis and human papilloma virus infection are in agreement with previously described risk factors for penile carcinoma. ${ }^{6}$ The main affection of glans (77\% of cases) is also comparable with other series. ${ }^{7}$

Bowen's disease and erythroplasia of Queyrat are both forms of carcinoma in situ. We reserved the designation erythroplasia of Queyrat for carcinoma in situ lesions occurring in the mucocutaneous region of the penis (glans), and Bowen's disease for the skin lesions of the foreskin and penile shaft. Concerning the other histological subtypes of SCC we did not find any association with location.

In our Dermatology department, Tis, Ta and T1a primary or recurrent tumours are almost exclusively treated with penis-conserving methods.
Medical therapy with imiquimod was offered for carcinoma in situ as an alternative to ablative techniques. Ablative techniques $\left(\mathrm{CO}_{2}\right.$ laser or cryotherapy) were used in carcinoma in situ and verrucous SCC, according to the availability of the technique and the surgeon's experience. Radical excision is the method of choice in cases of invasive SCC. Circumcision was chosen in cases of tumours of the foreskin.

Despite the important local recurrence rate $(53.3 \%)$, most of the cases were effectively treated with conservative modalities and only 3 local recurrences with extension to the erectile structures or the urethra had to be submitted to partial penectomy, leading to organ preservation in 27 (90\%) patients.

Conclusion: In spite of the high recurrence rate, conservative treatment modalities for SCC penile in lower pT stages $(\leq \mathrm{T} 1 \mathrm{a})$ did not compromise overall survival rate and may be advisable for this subset of patients in order to remove the tumour with no significant functional and psychological impact.

\section{REFERENCES}

1. Di Capua Sacoto C, Lujan Marco S, Morales Solchaga G, Budía Alba A, Pontones Moreno JL, Jimenez Cruz JF. Cancer of the penis. Our experience in 15 years. Actas Urol Esp. 2009;33:143-8.

2. Tchernev G. Sexually transmitted papillomavirus infections: epidemiology pathogenesis, clinic, morphology, important differential diagnostic aspects, current diagnostic and treatment options. An Bras Dermatol. 2009;84:377-89.

3. Lynch DF, Pettaway CA. Tumors of the penis. In: Walsh PC, Retik AB, Vaughan ED Jr, Wein AJ, Kavoussi LR, Novick AC, et al, editors. 8th ed. Campbell's Urology. Philadelphia: WB Saunders Co; 2002. p.2945-81.

4. Pizzocaro G, Algaba F, Horenblas S, Solsona E, Tana S, Van Der Poel H, et al. EAU penile cancer guidelines 2009. Eur Urol. 2010;57:1002-12.

5. Torezan L, Niwa AB, Neto CF. Photodynamic therapy in dermatology: basic principles. An Bras Dermatol. 2009;84:445-59.

6. Barocas DA, Chang SS. Penile cancer: clinical presentation, diagnosis, and staging. Urol Clin North Am. 2010;37:343-52.

7. Wanick FB, Teichner TC, Silva R, Magnanini MM, Azevedo LM. Squamous cell carcinoma of the penis: clinicopathologic study of 34 cases. An Bras Dermatol. 2011;86:1082-91.

\author{
MAILING ADDRESS: \\ Neide Pereira \\ Serviço de Dermatologia e Venereologia \\ Hospitais da Universidade de Coimbra \\ Praceta Mota Pinto \\ 3000-075 - Coimbra \\ Portugal \\ E-mail: neidepereira@sapo.pt
}

How to cite this article: Pereira N, Cabral AR, Vieira R, Figueiredo A. Conservative treatment of penile carcinoma - a retrospective study of 10 years. An Bras Dermatol. 2013;88(5):844-6. 